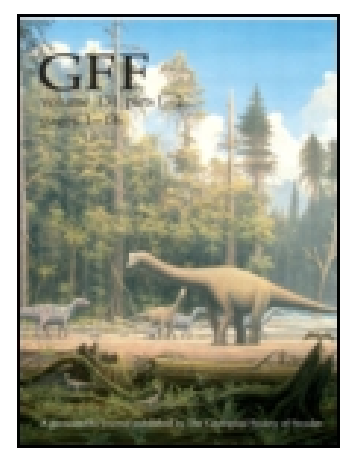

Geologiska Föreningen i Stockholm Förhandlingar

\title{
Sveriges Geologiska Undersökning och den praktiska riktningen af dess verksamhet
}

\section{Edvard Erdmann}

To cite this article: Edvard Erdmann (1907) Sveriges Geologiska Undersökning och den praktiska riktningen af dess verksamhet, Geologiska Föreningen i Stockholm Förhandlingar, 29:7, 444-453, DOI: 10.1080/11035890709445567

To link to this article: http://dx.doi.org/10.1080/11035890709445567

\section{曲 Published online: 06 Jan 2010.}

Submit your article to this journal

Џ Article views: 4 
444 GEOL. FörEx. FörHaNdL. Bd 29. Hăft. 7. Dec. 1907.

\section{Sreviges Geologiska Undersökning och den praktiska rikt- ningen af dess rerksimhet.}

Edvard Erdinax.

Vid genomläsandet af den i förra hüftet af Geologiska Föreningens Förhandlingar intagna uppsatsen: sTill frågan om den praktiska geologiens stälning inom vår statsförvaltning», af G. HaLLbERG, torde mången, på grund af däruti gjorda nttalanden, kunna fả en alltför ofördelaktig uppfattning om frulterna af Sveriges (Geologiska Undersöknings verksamhet och öfver hufvud taget om institutionens allmänna gagn. Derjümte kan den föreställningen lätt rinna insteg, att geologerna hufvudsaliligen eller $i$ alltför hög grad syssla med steoretiska spekulationer (sid. 372) och med sgeometriskt inritande af bergartsgränser» (sid. 374), ntan att $i$ allmänhet ägna synnerligt intresse ât geologiens tillämpning, detta si saknad af kontroll från praktiskt håll. (sid. 3599), såsom hr H. uttrycker sig. ${ }^{1}$

1 Rörande den mer cller mindre lämpliga formen för en del af de $i$ uppsatsen framställda klandren och anvisningurna vill jag icke inlata mig. Flera af de gjorda anmärkningarna torcle föröfrigt bero på fürf:s mindrc fallständiga kännedom om S. G. U:s arbeten och publikationer. Huru t. ex. eljest förklara yttrandet (of rerst a sid. 360), att S. G. U. bort , först och främst ägna sig ât kartläggning af våra berg och jordlager $i$ och för ökande af kunskapen om i jorden befintliga rảmaterial, i stallet för att s atbilda sig till ett allmänt geologiskt kartrerk, hvilket upptagit de znest olikartade gcolugiska spörsmål ete.s - - - Öka icke de gcologiska kartorna kunskapen om i jorden befintliga råmaterial? 
Bd 29. H. 7.] SVERIGES. GEOLOGISKA UNDERSÖKNING.

Ehuru en omorganisation och utvidgning af S. G. U. redan är föreslagen och delvis genomförd i syfte att, mera än hittills varit möjligt, kunna möta de $n u$ i hög grad stegrade krafven på institutionen, mâ det dock tillåtas att $i$ det följande anföra ett antal fakta, som visa, att S. G. U. dock, $i$ den utsträckning som förhillandena medyifvit, allt hittills baft öppen blick äfven för den praktiska verksamhetsriktningen och bemödat sig att, sả vidt möjligt, tillgodose icke endast rent vetenskapliga utan också praktiska lraf. - Det úr emellertid tydligt, att retenslapliga utredningar äro nödvändiga för att praktiska resultat skola kunna vinnas; nyttan af dem visar sig dock ej alltid genast, utan först långt senare, nïr nya ideer, nya riktuingar, nya behof och nya industrier uppstå.

Redan frãn första början af S. G. U:s verksamhet hade geologerna sig ålagdt - och äfven intresse för - att inom sina respeltive arbetsområden $i$ fultet eftersöka och genom borrning och gräfning m. m. utreda förekomsten, utbredningen och mäktigheten af kalksten, mürgel eller andra kalkhaltiga, för jordbruliet vilitiga aflagringar; och ej süllan hafva under dessa rekognosceringar landtbrukare och andra, med hvilka geologerna kommit $\mathrm{i}$ beröring, samtalsvis upplysts om ifrågavarande, för ortsbefolkningen flerstäles okända eller åtminstone oförstådda jordförbättringsmedels befintlighet, igenkännande, pröfning och tillgodogörande m. m., hvarjimte dessutom mången gång deras begäran om borrning på anvisade platser beredvilligt tillmötesgåtts.

År 1866 utgaf Undersökningens första chef en på dittills gjorda iakttagelser grundad ofversigtsliarta öfver huarfiga lcrans och hearfiga mergelns utbredning inom södra delen af Sverige, och år 1898, sedan undersökningarna och kartläggningen hunnit sträcka sig ofver allt större delar af landet, erhöll en bland geologerna, som ägde särskild insikt $\mathrm{i}$ äfven agronomiska förhållanden, uppdrag att sammanfatta de runna 
resultaten till en samma âr tryckt karta öfver kallstens- och mïrgelförekomsternas utbredning $i$ Sicrige och en denna åtföljande buslirifning, ett arbete hvillict säkerligen är af ej ringa praktiskt gagn. Beskrifningen redogör för de nämnda bergoch jordarternas utbredning, mäktighet. beskaffenhet och kalkhalt inom olika landsdelar, och den innehåller därjemte.en tabellarisk sammanställning af omkring 430 stycken å Sreriges Geologiska Undersöknings laboratorium utförda analyser of lallisicnar och dolomiter från ett stort antal lokaler inom skilda trakter af Srerige.

Vid tal om analyser må nämnas, att å samma laboratorium äro dessutom ntförda mera än 4,000 analyser af mürglar, leror och andra jorlarter samt i allt 1,600 af bergarter och mincral. Dessa kemiska bestämningar ïro naturligtvis gjorda $i$ afsikt att tjäna sảvïl retenskapliga som rent praktiska syften. Särskildt $i$ jordbrukets intresse är för ett mycliet stort antal mïrglar och andra jordarter halten af liarbonater (kolsyrad kalk och kolsyrad magnesia) och den i agrikulturafseende ytterst viktiga fosforsyran bestïmd. Förutom att analyserna mestadels äro infürda $\mathrm{i}$ de af $\mathrm{S}$. G. U. utgifna kartbladsbeskrifningarna och. andra publikationer, äro de sammanförda i en sürskild förteckning, hvilken förvaras å Geologiska Byrån, hrarest resultaten med beredvillighet meddelas härför intresserade.

Såsom bevis på det förtroende, S. G. U: åtnjutit, och att man $i$ allmänhet hyst en god tanke om den praktiska nyttan af dess arbete, må anföras, att genom institutionens försorg följande enskilda egendomar blifvit på ägarnes begäran och bekostnad agronomiskt och geologiskt undersökta och kartlagda i stor skala, nämligen Sliottorp och Dömmestorp i Hallands lïn (kartn och beskrifning tryckt 1881), Svalnüs i Roslagen (karta och beskr. 1887), Farsta och Gustafsberg i Stockholms län (karta och beslirifn. 1890) och Torreby i Bohus län (karta och beskrifn. 1892), samt att aitskilliga landsting och hushillningssillskap stält merlel till förfogande för att, tirli- 
gare än eljest lâtit sig göra, fả geologiska och geologiskt. agronomiska undersökningar utförda inom sina respelitive län. Jämtlands, Västennorrlands, Gäfleborgs, Gottlands, norra delen af Kalmar, Blekinge, Hallands och norra delen af Älfsborgs lïn jümte Dalsland hafva sålunda undersökts; resultatet füreligger i geologiska länskartor och länsbeshritningar. Dessa senare inrymma $i$ allmänhet en från praktisk synpunkt fattad redogörelse för den geologiska beskaffenheten af länet, för dettas tillgångar af $i$ ett eller annat af'seende värdefulla jordoch bergarter, malmer m. m. jämte antydningar eller upplysningar om deras eventuella tillgodogörande för jordbruks-, stenindustri- eller andra tekniska ändamål. Inom flera lün har S. G. U. lảtit genom Järnkontorets torfingeniör särskildt undersöka torfinossarna $\mathrm{i}$ afseende pã djup, torfbeskaffenhet och duglighet till odling eller bränsle samt däröfver upprätta tabeller. - Särskilda resor för efterforskande af för jordbruket eller eljest användbara jordarter hafva ntförts inom Gottlands län, Östergötlands mellersta del och trakterna liring sjön Siljan.

För att utröna, hururida inom landet funnes râämnen för en inhemsk superfosfattillverkning, utfördes i början af 1870talet, på förslag af dåvarande chefen för Sveriges Geologiska Undersökning, af därtill utsedda personer och med särskildt för ändamảlet beviljadt statsbidrag, ganska omfattande undersökningar inom flera provinser, där man hade anledning förmoda förekomst af fosforit och fosfarithaltiga bergarter. Uti en år 1873 af den $s$. $k$. fosforitkommittén afgifven underdånig berättelse redogöres för de vid undersökningen iakttagna fürekomsterna och uttalas förhoppningar om deras duglighet sãväl till rảmaterial inom superfosfatindıstrien som till användning för jordbruket utan förberedande behandling med syror, förboppningar hvilka dock hittills icke ledt till något industriellt åtgörande.

För utredande af apatitföreliomsters befintlighet och beskaffenhet inom hufrudsakligen Noirbottens lïn-samt möjlig- 
beternn för deras ekonomiskt fördelaktiga tillgodogörande utfördes âren 1889-1892 vidlyftiga rekognosceringar, försöksarbeten, smaltningar och kemiska analyser genom en af $\mathrm{Kgl}$. Maj:t tillsatt kommission (Apatitkommissionen), i hvilken S. G. U. genom trenne af sina geologer representerade den geologiska sakkinskapen. Under de geologiska rekognoscerin. garna och efterforskningarna lyckades man visserligen pâ âtskilliga platser upptäcka och konstatera apatit i mer eller mindre samlad myckenhet, men förekomsterna risade sig icke i allo sã lofvande, att någon industri hittills blifvit på desamma grundad. Flera uppsatser rörande ifrågavarande mineralförekomster äro frân institutionen utgifna.

Att iffren pâ det malmgcologislia omruidet $\mathrm{S}$. G. U. varit långt ifrản overksam eller likgiltig torde frangå af de publicerade redogörelserna för resultaten af dess arbeten och undersökningar på detta område, nämligen: Persbergets gruf cefält.(tr. 1875); Om malmfyndigheter inom Norrbottens län (Und. berätt. m. kartor, tryckt 1877); De malmförande trakterna i norra delen af Örebro lïn (Allmän geologisk beskrifning med berggrundskarta, år 1883, samt geol. kartor och beskrifningar ofver de viktigare gruffalten, tryckt 1889); Nasafjells zink- och silficrgrufvor (tr. 1895); Nordmarks grufvors odalfält (med atlas, tr. 1896); Kiirunuraara och Luossaraara järnmalmsfält (tr. 1898); Julkkasjärvi malmtrakt (Und. berätt. jämte atlas, tr. 1900) $\mathrm{m}$. fl.

I de förnt omförmalda länsbeskrifningarna redogöres för de respektive länens malmfyndigheter.

Hvad särskilat Norrland beträffar, har den bland institutionens geologer, som under en följd af âr nästan ensam haft på sin lott de mödosamma och krüfvande geologiska forskningsarbetena och färderna inom landets vidsträckta fjälltrakter, lyckats upptäcka flera förut okünda förekomster, nämligen jämmalm inom Krikkjokks kapell, Arjepluogs och Tärna socknar, krommalm i Frostrikens och Vilhelmina sock- 
nax, hiser och blyglans (i under vanliga förhållanden sannolikt brytvärd myckenhet) på minst 4 olika ställen i Norlbottens län; dessutom hafva nppdagats rika kalkstensförcliomster och marmorarter af sådana sällsynta typer, som rid de norska marmorbrotten ansetts vara mycket värdefulla, många förekomster af olivinsten, hvilkas praktiska bärvidd ännu. ej kan förutses; vidare pả ett par ställen asbest, tiiljsțc'll och rutil $\mathrm{i}$ sådana mängder, att åtminstone de förra kunna tỉnkas en gång blifva brytvärda. Slntligen hafva under dessa forskningsresor iakttagits de första större magnesitförckomsterna i Nord-Europa, nämligen de vid Tarrekaise i Rvikkjokk. Därvarande magnesit anses, från metallurgisk synpunkt betraktad, vara af synnerligen god beskaffenhet. Äfven af andra inom Norrbottens fjalltrakter arbetande geologèr hafva viktiga malmfynd gjorts. - Förtigas bör ej heller det indirekta praktiska gagn, som gcologen under sina fjüllresor sökt och äfren lyckats åstadkomma därigenom, att de âtföljande. biträdena och handtlangarne, tillhörande ortens befolkning, vid hvarje lämpligt tillfalle intresserats för och.undervisats i malmers och nyttiga minerals uppträdande, igenkännande och profining, en undervisning hvaraf redan det synliga praktisla resultat framgått, att Ekströmsbergs jürnmalmsfält och Stora Jürtas silfverfyndighet återupptäckts, samt att flera afserärda förekomster af magnesit (vid Måskaskaise och i närheten af Njunges i Krikkjokk) sedermera uppdagats af ett par bland nämnda följeslagare på grund af deras sålunda förvärfvade kunskaper och enligt anvisning utförda ihärdiga spanande.

Här torde ock kunna erinras om en annan form af den indirekta praktiska nytta; som varit en omedelbar följd af dessa fjällresor, nämligen den, som ligger i de afstyrliande vicidcn, då till geologen framställts begäran om värdelösa eller mindervärdiga fynds bedömande.

Vid förenämnda resor i Sveriges nordliga delar gjordes icke allenast geologiska rön, utan vunnos därjämte insikter i hydrogeologislia och hydrografiska förhållanden, insikter som 
tillgodogjordes genom den ifrảga varande geologens förordnande till ledämot $i$ den $s . k$. vattenfallskommittén.

Att bergarternas betydelse $i$ stenindustriellt afseende redan tidigt beaktades af chefen för Sreriges Geologiska Undersökning, framgår diiraf, att geologerna alltifrån bürjan af 1860talet, eller kanske tidigare, hade uppdrag att, under sina rekognosceringar, hrar och en på sin ort insamla, förutom de vanliga stufferna, äfven kubformade profstycken af lämpliga bergarter, som, sedermera vid stenhuggerier släthuggna och delvis polerade, afsågos att utgüra ett medel för bedö. mande af de olika stensorternas utseende $i$ bearbetadt tillstånd.

Redan vid 1866 års allmänna industriutställning i Stockholm kunde ett icke ringa antal - 115 stycken - sådana polerade stenkuber af institutionen utställas, hvarigenom uppmärksamheten blef fästad på Sveriges rikliga tillgångar af olikartade, för monumentala och byggnadsindamảl lämpliga stensorter. Sedermera har Undersökningens profsamling af sådana bergarter blifvit betydligt ökad och bildar numera en gansha aktningsvärd, ofta anlitad praktisk afdelning inom institutionens geologiska museum.

Under slutet af 1880- och början af 1890-talet bedrefs inom S. G. U. en liflig rerksamhet för främjandèt af Sreriges stenindustri. En af de dâ anstïllda geologerna fick nämligen tillfälle att alldeles sürskildt ägna sig àt denna gren af institutionens verksambet. $\mathrm{De}$ af honom $\mathrm{i}$ hithörande frảgor utarbetade uppsatserna, som då publicerades af S. G. U., röntè så stark afsüttning, att de allra flesta af dem nu üro fullständigt utgångna. Många äro ock de såräl muntliga som skriflliga råd och upplysningar i fråga om råmaterial m. m., som lämnats stenindustriens målsmän och idkare.

Utan tvifvel utgjorde det under of vannämnda tidsperiod vid S. G. U. visade intresset och bedrifna arbetet för stenindustrièns höjande en medverkande orsak till den uipplom- 
string af vår stenindustri, som därefter ägde rum, resulterande $i$ dels en allmännare användning af naturlig byggnadssten, dels en stegring af värdet af stenexporten från 3.7 mill. kronor år 1890 till 10.4 mill. kr. år 1900.

Och att nümnda intresse icke är dödt, bevisas däraf, att S. G. U. äfren under de senaste åren stått i lillig kontalit med de flesta större stenhuggerier och stenbrottsägare $i$ landet, hvilka också funnit med sin fördel förenligt att till verkets geologiska museum gratis öfverlämna instrultiva, pâ olika sütt bearbetade och delvis polerade profstycken af de bergartsvarieteter, som för nüruarunde fïras $\mathrm{i}$ marknaden; och äro dessa så att säga aktuella stenprof ordnade sảsom ett helt för sig i museet samt sålunda för allmänheten lätt åskảdliga.

För att $\mathrm{i}$ än vidare kretsar sprida künnedomen om inom landet förekommande användbara stenarter, malmer och andra râmaterial har S. G. U. vid de stora världsexpositionerna, vid geologiska kongresser samt vid inhemska landtbruks- och industriutstälningar - sammanlagdt ett tjugotal - anordnat rikhaltiga profsamlingar af hvad Srerige har att $i$ den vägen erbjuda, tillika med kartor och annat, som institutionen genom sin rerksamhet sammanbragt till belysning af sâval vetenskapliga som ekonomiskt-geologiska förhållanden; och har S. G. U. vid dessa tillfällen fảtt mottaga vackra erkännanden frân såväl fackmäns som utomstâendes sida.

Med tanke på den vikt, som utredandet af ett lands tillgång på fossilt bränsle äger, utgafs från S. G. U. år 1872, efter för ändamålet särskildt utförda undersökningar, en beskrifning öfver Slicincs stenkolsfürande formation tillika med en geologisk karta, visande utbredningen af denna formation och öfriga geologiska lagersystem inom vårt sydligaste landskap, ett arbete som otvifvelaktigt varit till praktiskt gagn, det nämligen att, pâ samma gång det utgjorde en ledning vid stenkolstillgângarnas eftersölande och tillgodogörande, däri- 
genom småningom stïfjades den vid nämnda tidpunlit och en tid framåt râdande osunda spekulationen i stenkolsinmutningar inom trakter, som pårisats vara icle kolförande. - Ar 1887 följdes ifrågavarande arbete af ett liknande, mera detaljeradt, i brilket hänsyn togs till resultaten af under mellantiden ntförda grufarbeten och djupborrningar. - Under förbercdelse är, sedan Kungl. Maj:t härför anvisat medel, ytterligare ett arbete rörande den viktiga frảgan om Skånes tillgảngar af stenkol samt för lerind nstrien m. m. lämpliga leror och skiffrar m. m.

Af hrad $i$ det föregående anförts, torde den opartiske lïsaren kunna bedöma, huruvida S. G. U. i själfva verket försummat sina praktisht-geologiska arbetsuppgifter, dả $i$ betraktande tages, att institutionen haft sig ålagdt att juimnsides härmed dels och i första rummet fullfölja den allmạinna geologiska kartläggningen, dels föra de rent vetenskapliga utredningarna utan störande uppehåll framåt. - Elıuruvial på intet sätt kan fönekas önskvärdbeten af att möjlighet bercdes S. G. F. att mera än hittills medhima en hel del praktiska uppgifter, fảr man dock erinra sig, att institutionens uppgift varit och fortfarande är i lika hög grad vetenskaplig som praktisk.

Till belysande af detta pâstâende mâ följande anföras:

a) Redan $i$ det första liungl. brefvet ảr 1858, rörande geologiska undersökningars anordnande i riket, fastställdes, att arbetet därvid sknlle utföras smed iakttagande af vetenskapens fordringar - - -

b) Med anledning af Kungl. Maj:ts framstallning till 18(j” -1863 ảrs riksdag om ytterligare anslag för de geologiska undersükningarnas fortsättande och utgifrande af dürpả gruudade kartor meddelade Rikets Ständer uti slirifrelse i nor. 1863 (N:o 149), att de stagit kiannedom om de virderika resultaten af de geologiska undersobningar, som dîmera humnit 
Bd 29. II. 7.] SVERIGES GEOLOGISLA UXDERsöKNING.

verkställas, samt, $i$ ofrerensstämmelse med de af Rikets Ständer vid de tvả sistförflutna riksmötena uttalade åsikter, höyt unpskattade dylika undersïliningars vilkt och betydelse ej blott $i$ ectensliapligt hänsccude, ${ }^{1}$ utan äfren för jordbrukets och mảnga andra näringars utveckling och förkofiran, ctc. - och att de fördenskull för nästa statsregleringsperiod beviljat det.för ifrågavarande ändamål äskade reservationsanslaget etc. - -

c) I sitt till Kungl. Maj:t d. 14 dec. 1907 afgifna underdảniga utlảtande om förslag rörande reglering af löneförhållandena m. m. vid Sveriges Geologiska Undersökning hemställer den ảr 1902 tillsatta löneregleringskommittén bland annat, zatt ã staten för S. G. U. må uppföras dels - - - , dels ock ett anslag ả 1,000 kronor att, efter beslut af Kungl. Maj:t, pá förslag frản verkets chef, disponeras till ersättning it verkets tjänstemän för vetensliapligt författarsknp."

' Kursireringen gjord af F. Enduas. 